Tomasz Korpysz

Uniwersytet Kardynała Stefana Wyszyńskiego

w Warszawie

t.korpysz@uksw.edu.pl
Data przesłania tekstu do redakcji: 14.12.2014

Data przyjęcia tekstu do druku: 09.01.2015

\title{
Rozwój semantyczny rzeczownika ,humor” w polszczyźnie. Przegląd leksykograficzny
}

Abstract: Korpysz Tomasz, Rozwój semantyczny rzeczownika „humor” w polszczyźnie. Przeglad leksykograficzny (Semantic Development of the Noun "Humor" in Polish Language. Lexicographic Overview). "Poznańskie Studia Slawistyczne" 9. Poznań 2015. Publishing House of the Poznan Society for the Advancement of the Arts and Sciences, pp. 287-301. ISSN 2084-3011 .

In the past fifteen years, the Polish linguistics faced a significant increase of interest in research into positive emotions: their naming, the ways in which they are expressed and manifested in the texts. The largest group of such research pieces concerns the field of joy and happiness and includes the noun "humor" and its derivatives. The semantic development of the above-mentioned noun can be traced basing on lexicographical sources: 'body fluids' (XVI c., the meaning disappears in the nineteenth century) - 'character, temperament, mood' (XVII c.) - 'good mood' (XVII c.) - 'whim, fantasy' (XVIII c., this meaning becomes soon characteristic solely for the plural uses) - 'type of comedy' (XIX c.). Being less aggressive, more intellectual and requiring developed cultural competence from both the sender and the receiver, "humor" in the latter sense quite soon begins to be regarded as more valuable than the other types of comedy. High evaluation is attributed also to "humor" in the sense of 'character, temperament', associated with positive emotions such as joy, serenity and optimism.

KEYwORDs: humor; lexicography; semantics; language of emotions; joy

\section{Emocje w badaniach językoznawczych}

Emocje - jako niezwykle istotny element ludzkiego życia: postrzegania rzeczywistości i wyrażania stosunku do niej; relacji międzyludzkich; reakcji werbalnych i pozawerbalnych na rozmaite doświadczenia itd. - są przedmiotem badań nie tylko biologii, neurologii i medycyny, lecz także większości nauk humanistycznych: przede wszystkim filozofii, psychologii i pedagogiki, ale też antropologii, socjologii czy kulturoznawstwa. Pozostają również w polu zainteresowania literaturoznawców 
i językoznawców, ponieważ emocje i emocjonalność oraz związane z nimi wartościowanie są istotnymi - choć w większości przypadków drugorzędnymi - składnikami wielu aktów porozumiewania się. Lingwiści badają m.in. sposoby nazywania, wyrażania i ujawniania się emocji w tekstach, ich funkcje czy konceptualizacje. Prace językoznawcze na temat emocji dzielą się na dwa typy: „1) dotyczące nazywania uczuć i sposobów mówienia o nich, 2) opisujące sposoby wyrażania uczuć" (Data 2000: 245$)^{1}$.

W opracowaniach lingwistycznych materiałem poddawanym oglądowi są przy tym zarówno szeroko rozumiane emocje, emocjonalność i emocjonalizmy (oraz ekspresja, ekspresywność i ekspresywizmy²) w polszczyźnie ogólnej (np. Kreja 1969; Wierzbicka 1971, 1999a, 1999b; Skubalanka 1972; Grzegorczykowa 1978; Nowakowska-Kempna 1986, 1995, 2000; Grabias 1991; Borek 2001), jak i przejawianie się tych zjawisk w rozmaitych odmianach języka (m.in. w języku mówionym - np. Sopolińska 2004, języku młodzieży - np. Korpysz 2009, socjolekcie uczniów - np. Smól 2006 czy gwarach - np. Czyż 2004), gatunkach i typach tekstów (m.in. w tekstach reklamowych - np. Zimny 2004, nagłówkach prasowych - np. Pałuszyńska 2002 czy nekrologach - np. Grzesiak 1991), różnego rodzaju jednostkach języka (m.in. w strukturach składniowych - np. Grzesiuk 1985, frazeologizmach - np. Pajdzińska 1990, formacjach słowotwórczych - np. Grabias 1991, konkretnych częściach mowy, choćby rzeczownikach - np. Spagińska-Pruszak 2005 czy też wykrzyknikach np. Wojtczuk 2004), organizacji graficznej tekstu (przede wszystkim ortografii i interpunkcji - np. Zawilska 2004, a także charakterystycznych dla Internetu emotikonach - np. Benenowska 2004), fonicznej warstwie wypowiedzi (np. Szykulska 2003), konkretnych utworach literackich, ich zbiorach lub twórczości jednego autora (m.in. w Vade-mecum Cypriana Norwida - cf. Sobotka 2002, twórczości poetyckiej ks. Jana Twardowskiego - cf. Rybka, Sławek 2004 czy powieści Sławka Shutego BLOK - cf.

${ }^{1}$ Terminy: „uczucia” i „emocje” nie są synonimami całkowitymi i kompletnymi (cf. np. Puzynina 2000: 12), w wielu pracach językoznawczych są one jednak używane zamiennie.

${ }^{2} \mathrm{~W}$ literaturze przedmiotu spotkać można ujęcia traktujące wymienione pojęcia jako synonimy, jak też takie, które wskazują na ich semantyczną odrębność i nadrzędność zakresową ekspresywności. W tym miejscu kwestia ta - jako niezwiązana z zasadniczym tematem niniejszego tekstu - jest jedynie sygnalizowana. 
Chodowiec 2006). Krystyna Wojtczuk, omawiając językoznawcze prace na temat emocji powstałe w latach 1997-2007, dzieli je na dwie zasadnicze grupy: pierwsza „wpisuje się (...) w paradygmaty językoznawstwa wewnętrznego, ujmującego język autonomicznie, niekontekstowo", druga zaś „tkwi w lingwistyce pojmowanej w sposób otwarty, uwzględniającej konteksty języka wynikające z jego związku z literaturoznawstwem, socjologią, psychologią, etnologią, aż po najszersze konteksty antropologii kulturowej" (Wojtczuk 2009: 263).

Szczególną grupę prac dotyczących emotywnego aspektu języka stanowią te, w których analizuje się konkretne emocje: sposoby ich nazywania, wyrażania oraz przejawiania się w tekstach. Jak przy tym zauważa Agnieszka Mikołajczuk, przez długi czas „dominujący przedmiot studiów, zwłaszcza w opracowaniach psychologicznych i językoznawczych, stanowiły wśród zjawisk emocjonalnych uczucia negatywne wraz z ich przejawami oraz ich językowe wykładniki, np. gniew, złość i agresja, lęk, smutek i melancholia, nieśmiałość, zazdrość i wiele innych" (Mikołajczuk 2009: 7). Polscy językoznawcy dopiero w ostatnich latach częściej zaczęli zajmować się uczuciami pozytywnymi, a zwłaszcza szeroko rozumianym polem szczęścia i radości (np. Jagodzińska 2000; Bartnicka 2001; Duszak, Pawlak 2005; Mikołajczuk 2006; 2007, 2009; Peisert 2006; Sydiaczenko 2006; Wojtczuk 2006; Bujak-Lechowicz 2007; Balcerzak 2008; Waszakowa 2008; Korpysz 2010; Siatkowska 2013) .

\section{2. „Humor” w polszczyźnie}

Radość, dość powszechnie uznawana za jedną z emocji podstawowych, organizuje w polszczyźnie ,rozległe pole znaków językowych” (Mikołajczuk 2009: 8), w którym znajdują się m.in. takie leksemy, jak: „,dowcip”, „radość”, „szczęście”, ,śmiech”, „uśmiech”, „wesołość”, „,zadowolenie”, ,żart”. Do pola tego należy również rzeczownik „humor”, utworzone od niego derywaty oraz zawierające je wyrażenia. Izaak Passi stwierdza: „Mało jest słów, które - jak humor - są przedmiotem tak wielu

${ }^{3}$ Rzecz jasna, istnieją również podobne, wcześniejsze prace (np. Buttler 1977, 1978; Siatkowska 1988), lecz są one bardzo nieliczne. 
(niewinnych) nadużyć. (...) słowem «humor» oznacza się wszystko, co w jakimś stopniu dotyczy śmieszności i różnych form, werbalnych i niewerbalnych, jej realizacji” (Passi 1980: 217). Należy podkreślić, że uwaga bułgarskiego badacza jest nieco zbyt daleko idąca (zwłaszcza w odniesieniu do polszczyzny), ale leksem ten rzeczywiście bywa definiowany bardzo różnie z rozmaitych perspektyw.

Z literaturoznawczego punktu widzenia ,humor” to np.: 1. 'dyspozycja psychiczna, zarówno twórcza, jak i odbiorcza, do ujmowania zjawisk życia i sztuki w kategoriach komizmu'; 2. 'odmiana komizmu będącego wyrazem dyspozycji twórczej’ (cf. Głowiński, Kostkiewiczowa, Okopień-Sławińska, Sławiński 1988: 187). Z kolei w ujęciu socjologicznym i psychologicznym ,humor” jest rozumiany np. jako 1. 'stan (uwarunkowany sytuacyjnie) psychiki'; 2. 'trwała postawa wobec rzeczywistości' (cf. Matusewicz 1976: 47-48).

Różnorodności definicji towarzyszy wielość koncepcji wyznaczających granice zakresowe między pojęciami „komizmu”, „humoru” i ,śmieszności”4. Jak zauważa Bogdan Dziemidok: ,jedną z największych trudności dla teoretyka komizmu jest konieczność uporządkowania i sprecyzowania pojęć dotyczących przejawów komizmu i hierarchiczne uporządkowanie różnych jego form" (Dziemidok 1967: 57), podobnie pisze wielu innych badaczy ${ }^{5}$. W polskiej tradycji za pojęcie najszersze zakresowo, nadrzędne, najczęściej uznaje się „komizm”, a „humor” i ,śmieszność” traktuje się jako pojęcia podrzędne, określenia pewnych specyficznych typów komizmu6. „Humor” jest przy tym określany jako „wysoce

${ }^{4} \mathrm{Z}$ filozoficznego punktu widzenia relacje między komizmem a śmiesznością interesująco analizuje Denis Bertrand (1994: 127-141).

${ }^{5}$ Izaak Passi stwierdza np.: „Jedną z najtrudniejszych kwestii w estetyce śmieszności jest określenie granic humoru, sprecyzowanie jego pojęcia, a stąd też odróżnienie go od innych bliskich mu form w o wiele szerszej dziedzinie komizmu" (Passi 1980: 217).

${ }^{6} \mathrm{~W}$ tradycji anglosaskiej pojęciem nadrzędnym jest z kolei „humor”. W związku z tym, że literatura anglojęzyczna dotycząca komizmu jest bardzo bogata, w ostatnich latach także w Polsce zaczęto używać jako nadrzędnej nazwy „humor”; coraz częściej - na wzór języka angielskiego - mówi się też o badaniach humorologicznych. Świadectwem tej zmiany jest chociażby używanie leksemu ,humor" w tytułach nowszych polskich opracowań z tego zakresu: cf. np. Adamczuk 1993; Abramowicz, Bertrand, Stróżyński 1994; Chłopicki 1995; Gajda, Brzozowska 2000; Mazur, Rumińska 2007; Kwiatkowska, Dżereń-Głowacka 2008-2009; Kwiatkowska, Stanecka 2012; Karwatowska, Tymiakin 2013; Dunaj, Morawska, Latoch-Zielińska 2014. 
skomplikowana reakcja na zjawiska komiczne oceniane dodatnio" (Krzyżanowski 1984: 154)7, ,postać komizmu, która niejako bezinteresownie, w postawie nieagresywnej, pełnej wyrozumiałości, optymizmu, ujawnia sprzeczność między rzeczywistą naturą świata a pozorami” (Gołaszewska 1987: 21) czy też „rodzaj komizmu wyróżniający się rangą intelektualną i emocjonalną" (Garczyński 1989: 11) ${ }^{8}$. Współczesne rozumienie - czy raczej rozumienia - „humoru” dalekie są przy tym od jego znaczeń pierwotnych. Jak zmieniała się semantyka opisywanego leksemu?

Polski rzeczownik ,humor”9 jest zapożyczeniem z języka łacińskiego, w którym słowo „humor”, „umor” oznaczało 'wilgoć, mokrość' (np. Sławski 1952-1956) ${ }^{10}$. Pojawił się on w polszczyźnie stosunkowo późno: nie notuje go jeszcze Słownik staropolski, obejmujący wyrazy i wyrażenia z tekstów polskich oraz z glos polskich do tekstów łacińskich (wydanych drukiem lub pozostających w rękopisach) powstałych od czasów najstarszych do roku 1500 (Urbańczyk 1956-1959) ani Stownik polszczyzny Jana Kochanowskiego (Kucała 1994). W źródłach z XVI wieku „humor” już się jednak pojawia, co poświadcza Słownik polszczyzny XVI wieku, w którym notowane są dwa użycia, oba w liczbie mnogiej, w znaczeniu 'płyny organiczne w ciele ludzkim' (cf. Mayenowa 1974). Takie rozumienie

${ }^{7}$ Autor dodaje, że humor „występuje tam, gdzie pod powłoką śmieszności dostrzegamy zjawiska tego cechy wartościowe”, a „oko wielkiego humorysty nie daje się zwieść pozorom i dostrzega wielkość w śmieszności, tak że humor jest swoistą postacią optymizmu" (Krzyżanowski 1984: 154).

${ }^{8} \mathrm{~W}$ dalszej części szkicu autor pisze m.in.: „Wyróżnia się on wysoką rangą intelektualną, bo jest w nim coś z zadumy nad życiem, bo dostrzeganie humoru wymaga czegoś więcej niż wesołego usposobienia i talentu do figlowania, (...) wymaga inteligencji, kultury, a nieraz i wiedzy. (...) Humor wyróżnia się także rangą emocjonalną, bo to komizm bez żółci, bliższy miłości niż nienawiści, objawia się raczej dobrodusznością niż zjadliwością, wyrozumiały, łagodny, nienapastliwy (...). Humor nie ciska gromów, a nawet, gdzie się tylko da, widzi dobro. (...) Humor płynie zarówno z żywości myśli, jak i z dobroci serca, ma podtekst refleksyjny, a niekiedy i liryczny. (...) Humor ma wymiar etyczny nie tylko dzięki ciepłej życzliwości, ale także dzięki stosunkowi do prawdy. (...) Humor polega nie na tworzeniu kombinacji fantastycznych, nie na grze wyrazów, ale na sumiennym oglądaniu rzeczy co najmniej z dwu stron: dobrej i złej, małej i wielkiej, ciemnej i jasnej" (Garczyński 1989: 11-19).

${ }^{9}$ Rozwój analizowanego leksemu w polszczyźnie bywał już przedmiotem opisu, jednak każdorazowo był to opis skrótowy, jedynie zarysowany - cf. Krasowska 2013: 103-104; Siatkowska 2013: 142-143.

${ }^{10}$ Autor definiuje „humor” dość szeroko, jako "chwilowy stan usposobienia, nastrój; pogodne usposobienie, wesołość, dowcip; wesołe i dowcipne przedstawienie ludzkich słabości’. 
omawianego leksemu przejęto z języka łacińskiego i starożytnej oraz średniowiecznej medycyny, która

wyróżniała cztery humory: krew, żółć, czarną żółć, flegmę. A cały szereg stanów chorobowych przypisywała zaburzeniom równowagi w proporcjach płynów ustrojowych. Charakterystycznym objawem trwałego zakłócenia równowagi humorów było (...) nietypowe zachowanie. $Z$ czasem właśnie owe objawy - wybuchy gniewu, popadanie w ekstremalne nastroje, labilność emocjonalną - zaczęto nazywać humorami (Wieczorek 2000: 21).

Na gruncie polszczyzny zarysowany wyżej proces opartych na metonimii zmian semantycznych zaczął zachodzić w wieku XVII: w tekstach z tego okresu „humor” (jego pierwsze wystąpienia w źródłach słownika polszczyzny tego okresu pochodzą z połowy wieku) to 'nastrój, usposobienie' (cf. Gruszczyński) ${ }^{11}$, w pismach Jana Chryzostoma Paska to już nawet 'pogodny nastrój, wesołość, fantazja, dowcip' (Koneczna, Doroszewski 1965 $)^{12}$. Pierwotne znaczenie omawianego rzeczownika zachowało się jednak dość długo. W słowniku Lindego ,humor” opisywany jest jeszcze dwojako:

medic. słowo humory, które możemy zwać rozciekami, oznacza wszystkie substancye płynne, rozpłodzone w ciele ludzkim trawieniem pokarmów (...). Humory w stanie naturalnym są łagodne, figurę okrągłą mające, gęstość do naczyń proporcjonalną. moral. skłonność, sposób myślenia, gust, smak, wola, fantazya (Linde 1859).

Leksykograf przytacza kilka przykładów użyć tego rzeczownika (m.in. „Humor mój jest wesoły”, „Cóż to, pana w tak kwaśnym zastaję humorze?”), a także derywaty „humorek” ('zły humor, kaprys') i „humorowaty” ('pełen humorów, kaprysów'). Z przywołanych połączeń oraz ze znaczenia przymiotnika „humorowaty” wynika, że mimo braku tego elementu w eksplikacji rzeczownik ,humor” oznaczał w tym czasie nie tylko 'nastrój', lecz także 'kaprys'. Intensywny rozwój semantyczny analizowanego leksemu

${ }^{11}$ Cytowany słownik notuje także przysłówek ,humorowacie” - 'okazując niezadowolenie, zły nastrój, złe usposobienie; kapryśnie, z dąsami’ oraz przymiotnik „humorowaty” - 'mający niestałe usposobienie, pełen kaprysów' (cf. Gruszczyński).

${ }^{12}$ Dane z tego słownika nieco podważają zatem stwierdzenie Ewy Siatkowskiej, że „znaczenie określonej dyspozycji psychicznej wykształciło się w XVIII wieku, szybko się upowszechniając" (Siatkowska 2013: 143). Znaczenie to, pojawiło się w polszczyźnie, jak widać, już wcześniej. 
(wyraźne zwiększenie liczby znaczeń, powiązanie z komizmem i sztuką, w tym sztuką wysoką, a także z filozofią) nastąpił w wieku XIX, co potwierdzają słowniki obejmujące leksykę tego okresu - zarówno ogólną (tzw. słownik wileński oraz słownik warszawski), jak i idiolektalną (Adama Mickiewicza i Cypriana Norwida). Warto więc bliżej przyjrzeć się danym pochodzącym z tych leksykonów. Interesujące są przy tym zwłaszcza oba słowniki języka autorskiego, ponieważ pozwalają prześledzić sposób rozumienia i używania rzeczownika „humor” w zamkniętych, wewnętrznie bardzo zróżnicowanych, a jednocześnie mających jednego autora korpusach tekstów.

W utworach Adama Mickiewicza „humor” pojawia się 68 razy. W większości kontekstów (66) w znaczeniu 'nastrój, usposobienie'. Opisywany bywa wówczas jako m.in.: „dobry”, „gniewny”, „gorzki”, „,ironiczny”, „kwaśny”, ,poetycki”, ,pogodny”, „wesoły”, „zły”. Dwukrotnie występuje też w liczbie mnogiej w znaczeniu 'kaprysy, dąsy' (Górski, Hrabec 1962).

Jak widać, Mickiewicz już ani razu nie użył słowa „humor” na oznaczenie płynów ustrojowych. To pierwotne znaczenie było jednak, jak się zdaje, w XIX wieku nadal żywe, o czym świadczyć może to, że w słowniku wileńskim odnotowane jest ono jako pierwsze: 'rozciek, wszelka substancja płynna, rozpłodzona w ciele ludzkiem trawieniem pokarmów' (definicja ta powtarza sformułowanie Lindego). Drugie znaczenie, opisane jako przenośne, to 'skłonność, usposobienie ducha; sposób myślenia, gust, smak, wola', trzecie: 'kaprys, zły humor', czwarte zaś: 'wesołość dowcipna i satyryczna; oryginalność żartobliwa' (Zdanowicz 1861). Słownik notuje też kilka derywatów: „humoralizm”, ,humorek”, „humorowaty”, „humorysta” (co istotne: w dwóch znaczeniach: 1. 'lekarz objaśniający wszystkie choroby ze zmiany części płynnych w ciele ludzkiem', 2. 'pisarz humorystyczny, t.j. w którego utworach przebija się humor, czyli żartobliwa oryginalność'), „humorystycznie”, ,humorystyczność”, „humorystyczny”, „humorystyka” (Zdanowicz 1861).

Rodzina słowotwórcza „humoru” w pismach Cypriana Norwida liczy cztery leksemy użyte łącznie 33 razy: „humor” (30 użyć, w tym jedynie pięć w poezji) oraz użyte tylko raz: „humorystyka”, „humorystyczny”, „, humorysta" (dane za: Puzynina, Korpysz 2009). Podstawowy rzeczownik tego pola najczęściej (21 razy) występuje w ogólnym znaczeniu 'charakter, usposobie- 
nie; nastrój ${ }^{13}$. Tak rozumiany „humor” może być „,dobry”, co inni „,podziwiają”, a także ,jowialny”. Może być jednak również „zły” - takiego należy „unikać” i starać się go ,poprawić”, np. lekturą ,arcyzabawnego listu”.

Drugie znaczenie obecne w pismach Norwida, to 'dobry nastrój, wesołe usposobienie, pogoda ducha; zdolność dostrzegania i opisywania tego, co zabawne ${ }^{14} \mathrm{i}$ jest aktualizowane dziesięciokrotnie. Tak rozumiany humor jest przez poetę wartościowany pozytywnie, często nawet bardzo wysoko - nie tyle jako cecha, ile raczej świadomie przyjęta postawa wobec świata i siebie samego. Postawa związana z uważnym przyglądaniem się rzeczywistości i jednocześnie z pewnym dystansem wobec tego, co człowieka spotyka, a przy tym z poczuciem własnej wartości i godności, które należy zachowywać niezależnie od okoliczności, także w sytuacjach granicznych. Co charakterystyczne, Norwid kilkakrotnie pisze w tym kontekście o sobie i swoich trudnych przeżyciach. Uderzający jest zwłaszcza list do Bronisława Zaleskiego, powstały już po dramatycznych doświadczeniach wojny francusko-pruskiej i oblężenia Paryża oraz komuny paryskiej: „Mój humor obowiązuje mnie, abym był skłonnym zrobić żart, kiedy mogę nie mieć zupełnego śniadania lub zupełnych rękawiczek, albo kiedy na ulicach miasta mogę być (bez reparacji, jak bywali) rozstrzelanym" (Norwid 1971-1976: X, 58-59).

Trzecie znaczenie - 'zły nastrój; kaprys' - pojawia się w pismach Norwida tylko raz. Raz też - w poemacie Quidam - jako jeden z przejawów wyraźnej archaizacji języka tego utworu, zastosował poeta słowo „humory” (w liczbie mnogiej) w dawnym znaczeniu czterech płynów w organizmie człowieka (krew, żółć, czarna żółć, flegma), których wzajemne relacje decydowały o zdrowiu, samopoczuciu i zachowaniu ludzi.

Jak widać, Cyprian Norwid wykorzystał w swoich tekstach więcej znaczeń rzeczownika „humor” niż Adam Mickiewicz (szerzej cf. Korpysz

${ }^{13}$ Humor rozumiany jako charakter, usposobienie jest czymś stałym lub przynajmniej długotrwałym, z kolei rozumiany jako nastrój - czymś czasowym, zmiennym, jednakże ze względu na to, że w badanym materiale trudno jest wyznaczyć ostre granice między tymi rozumieniami, oba odcienie semantyczne (w niektórych słownikach opisywane jako dwa odrębne znaczenia) połączono tu w jedno ogólniejsze znaczenie - podobnie jak w przywoływanym wyżej Słowniku języka Adama Mickiewicza.

${ }^{14}$ Ze względu na to, że oba aspekty znaczeniowe w badanym materiale często łączą się ze sobą, nie wyodrębniono tu - jak w niektórych słownikach - dwóch osobnych znaczeń. 
2015), jednak w polszczyźnie XIX-wiecznej występowało jeszcze większe zróżnicowanie semantyczne analizowanego leksemu, co poświadcza słownik warszawski, w którym „humor” ma aż sześć definicji (dwie pierwsze dość zbliżone): 1. 'charakter, usposobienie', 2 'usposobienie, nastrój duchowy, animusz', 3. 'dobry, wesoły humor, dobre, wesołe usposobienie, fantazja', 4. '(w estetyce) odmiana komizmu: żartobliwe i dobroduszne ośmieszanie przywar i dziwactw; naiwny dowcip; dowcip ośmieszający w sposób pobłażliwy; śmieszność wynikająca z przedstawienia osób i rzeczy poważnych a. podniosłych w rysach banalności pospolitej, lub osób i rzeczy pospolitych, banalnych - w rysach poważnych i podniosłych', 5. 'dziwny humor, dziwaczne usposobienie, fantazja, widzimisię, kaprys', 6. oznaczone jako przestarzałe, 'w lm. lek. ciecze, płyny ustrojowe w ogólności' (cf. Karłowicz, Kryński, Niedźwiedzki 1900). Słownik ten notuje także liczne derywaty: „humoralny”, „,humorek”, „humoreska”, „humorowaty”, „,humory” (jako plurale tantum), „humorysta” (podobnie, jak w słowniku wileńskim, w dwóch znaczeniach, ale ze znamienną różnicą kolejności: 1. 'ten, co traktuje rzeczy z humorem; pisarz obdarzony humorem; opowiadający dowcipnie', 2. oznaczone jako przestarzałe, 'lekarz objaśniający wszystkie choroby ze zmiany części płynnych w ciele ludzkim'), „humorystka”, „humorystycznie”, „,humorystyczność”, „humorystyczny”, „humorystyka” (cf. Karłowicz, Kryński, Niedźwiedzki 1900).

Słownik języka polskiego pod redakcją Witolda Doroszewskiego odnotowuje już tylko cztery znaczenia „humoru”: 1. 'zdolność dostrzegania zabawnych stron życia, wesołość, pogoda w ustosunkowaniu do świata', 2. 'chwilowy stan usposobienia, nastrój', 3. wstępujące tylko w liczbie mnogiej - 'kaprysy, dąsy' oraz 4. opatrzone kwalifikatorem „dawne”: 'płyn organiczny'. Ponadto występują w nim derywaty: „humorystyczny”, „humorystycznie”, ,humorysta”, ,humorystka”, „, humorystyczność”, „humorystyk” oraz „humoryzm” (cf. Doroszewski 1958).

W Uniwersalnym słowniku języka polskiego rzeczownik „humor” ma trzy znaczenia: 1. 'zdolność dostrzegania zabawnych stron życia', 2. 'chwilowy stan usposobienia, zwłaszcza: pogodny nastrój' oraz opatrzone kwalifikatorem „książkowy”: 3. 'przedstawienie czegoś w zabawny sposób; zabawne, komiczne sceny, sytuacje, dialogi itp.’ (cf. Dubisz 2003).

Najnowsze źródło leksykograficzne, w którym występuje analizowany leksem, to Wielki słownik języka polskiego (cf. Żmigrodzki 2007). W nim 
również odnotowano trzy znaczenia: 1. 'umiejętność dostrzegania tego, co zabawne, oraz rozśmieszania innych', 2. 'cecha tego, co nas bawi lub rozśmiesza' oraz 3. 'nastrój' z podznaczeniami: 3a. 'to, jaki ktoś ma nastrój' oraz 3b. 'dobry nastrój'.

\section{Uwagi podsumowujące}

Jak widać z powyższych danych leksykograficznych, rozwój semantyczny rzeczownika „humor” w polszczyźnie jest przejrzysty i łatwy do odtworzenia: 'płyny ustrojowe' (XVI w., to znaczenie zanika w XIX w.) 'charakter, usposobienie, nastrój' (XVII w.) - 'dobry nastrój' (XVII w.) - 'kaprys, fantazja' (XVIII w., to znaczenie szybko staje się charakterystyczne wyłącznie dla użyć w liczbie mnogiej) - 'rodzaj komizmu' (XIX w.). Warto przy tym podkreślić, że humor $\mathrm{w}$ tym ostatnim rozumieniu - jako bardziej intelektualny, mniej agresywny, wymagający rozwiniętych kompetencji kulturowych zarówno od nadawcy, jak i odbiorcy - dość szybko zaczęto uznawać za bardziej wartościowy od innych rodzajów komizmu.

Wysoko oceniany jest też „humor” w znaczeniu "charakter, usposobienie'; już XIX-wieczni teoretycy wskazywali przy tym, że ,istotą humoru jest nie tylko wesołość, ale także powaga, przenikliwość umysłu, a nawet «śmiech przez łzy»" (Bogołębska 2000: 325) ${ }^{16}$. Humor w takim rozumieniu to szczególna, oparta na dystansie do siebie i świata postawa $^{17}$, jak to określa Krzysztof Wieczorek: „funkcja własnego usytuowania w przestrzeni wartości" (Wieczorek 2000: 19). Postawa humorystyczna jest „postawą kontemplacyjno-refleksyjną” (Dziemidok 1967: 101); związana jest przy tym z głęboką samowiedzą podmiotu, a jednocześnie „może przynosić komuś wiedzę o sobie, której ów wolałby nie mieć" (Crithley

\footnotetext{
${ }^{15}$ Prawdopodobnie na przełomie XVI i XVII wieku istniało w polszczyźnie także niepoświadczone w źródłach znaczenie 'stany chorobowe i zachowania związane z zachwianiem równowagi płynów ustrojowych', które tłumaczyłoby referowaną zmianę semantyczną.

${ }^{16}$ Piotr Chmielowski pisał, że humor ,jest to nastrój duszy, łączący w sobie bystrą obserwację, bogatą wyobraźnię, wytworny dowcip żartobliwy, ironię (...) z głębokim, szczerym, tkliwym, ale w objawach swych skąpym uczuciem” (za: Bogołębska 2000: 325).

${ }^{17}$ Simon Critchley pisze wręcz, że ,humor można postrzegać jako jeden z warunków zajęcia krytycznej postawy wobec zdarzeń życia codziennego" (2012: 66).
} 
2012: 113). Co istotne: „nie koncentruje się wyłącznie ani na wadach, ani na zaletach świata i ludzi. Ukazuje świat we właściwych proporcjach i nie uogólnia pochopnie. Przeciwstawia się zarówno skrajnemu pesymizmowi, jak też bezmiernemu optymizmowi, zarówno apologetyce, jak też daleko posuniętej negacji” (Dziemidok 1967: 101). Jest to postawa, która zdaniem wielu autorów zawsze powinna towarzyszyć człowiekowi świadomemu, niezależnie od choćby najtrudniejszych okoliczności życiowych. „Humor”, szczególnie w tym ostatnim znaczeniu, ściśle związanym z emocjami pozytywnymi, z szeroko rozumianą radością i pogodą ducha, jest więc rzeczywiście „leksemem aksjologicznym” (Siatkowska 2013). Analizowanie sposobów rozumienia i używania tego leksemu oraz innych leksemów z pola semantycznego komunizmu i radości (zwłaszcza w konkretnym idiolekcie czy też wybranej grupie tekstów lub pojedynczej wypowiedzi), włączone w szersze badania języka emocji „stanowią - jak się wydaje - klucz do poznania wielu zachowań człowieka, np. ludzkiego wartościowania i oceniania” (Wojtczuk 2009: 270).

\section{Literatura}

Abramowicz M., Bertrand D., Stróżyński T. (red.), 1994, Humor europejski, Lublin. Adamczuk E., 1993, Komunikowanie się poprzez humor, Lublin.

Balcerzak M., 2008, Uśmiech jako komunikatywny gest mimiczny o bogatej semantyce, w: Pojęcie - stowo - tekst, red. R. Grzegorczykowa, K. Waszakowa, Warszawa, s. $167-180$.

Bartnicka B., 2001, Łączliwość składniowo-leksykalna rzeczownika ,śmiech” w twórczości Stefana Żeromskiego, „Prace Filologiczne” t. 46, s. 49-57.

Benenowska I., 2004, Emocje w Internecie, w: Funkcja emocjonalna jednostek językowych i tekstowych, red. K. Wojtczuk, A. Wierzbicka, Siedlce, s. 9-20.

Bertrand D., 1994, Ironia i humor: dyskurs wywracajacy, w: Humor europejski, red. M. Abramowicz, D. Bertrand, T. Stróżyński, Lublin, s. 125-141.

Bogołębska B., 2000, Między humorem, dowcipem i komizmem (śmiesznościa), czyli o zmaganiach terminologicznych autorów poetyk XIX i poczatku XX w., w: Świat humoru, red. S. Gajda, D. Brzozowska, Opole, s. 323-329.

Borek M., 2001, O wyrażaniu uczuć i emocji, w: Język w komunikacji, t. 2, red. G. Habrajska, Łódź, s. 228-234.

Bujak-Lechowicz J., 2007, Portret językowy szczęścia w wypowiedziach młodzieży i osób po 60. roku życia, w: Antynomie wartości. Problematyka aksjologiczna wjęzykoznawstwie, red. A. Oskiera, Łódź, s. 195-208. 
Buttler D., 1977, Grupa semantyczna przymiotników polskich o znaczeniu 'pozostajacy w zwiąku z radościa', „Prace Filologiczne” t. 27, s. 271-286.

Buttler D., 1978, Łączliwość przymiotników o znaczeniu 'związany z radością', „Prace Filologiczne" t. 28, s. 207-221.

Chłopicki W., 1995, O humorze poważnie, Kraków.

Chodowiec T., 2006, Wybrane sposoby wyrażania emocji w powieści hipertekstowej „BLOK” Stawka Shuty, w: Wokót językowej funkcji emocjonalnej. Fakty dawne $i$ współczesne, red. K. Wojtczuk, V. Machnicka, Siedlce, s. 33-44.

Crithley S., 2012, O humorze, Warszawa.

Czyż D., 2004, Elementy emocjonalne w nazwach nosicieli cech w gwarze łomżyńskiej, w: Funkcja emocjonalna jednostek językowych i tekstowych, red. K. Wojtczuk, A. Wierzbicka, Siedlce, s. 21-29.

Data K., 2000, W jaki sposób językoznawcy opisuja emocje?, w: Język a kultura, t. 14, Uczucia w języku i tekście, red. I. Nowakowska-Kempna, A. Dąbrowska, J. Anusiewicz, Wrocław, s. 245-252.

Dunaj E, Morawska I., Latoch-Zielińska M. (red.), 2014, Humor w kulturze i edukacji, Lublin.

Duszak. A., Pawlak N. (red), 2005, Anatomia szczęścia: emocje pozytywne w językach i kulturach świata, Warszawa.

Dziemidok B., 1967, O komizmie, Warszawa.

Gajda S., Brzozowska D. (red.), 2000, Świat humoru, Opole.

Garczyński S., 1989, Anatomia komizmu, Poznań.

Gołaszewska M., 1987, Śmieszność i komizm, Wrocław-Warszawa-Kraków-Gdańsk- Łódź 1987.

Grabias S., 1991, O ekspresywności języka. Ekspresja a słowotwórstwo, Lublin.

Grzegorczykowa R., 1978, Struktura semantyczna wyrażeń ekspresywnych, Wrocław.

Grzesiak R., 1991, O sposobach wyrażania wartości w tekstach nekrologów, w: Język a kultura, t. 3, Wartości w języku i tekście, red. J. Puzynina, J. Anusiewicz, Wrocław.

Grzesiuk A., 1985, Składnia wypowiedzi emocjonalnych, Lublin.

Jagodzińska J., 2000, Uśmiech i śmiech $w$ dyskusjach internetowych - o sposobach zapisu uczuć towarzyszacych wypowiedzi, „Poradnik Językowy” z. 3, s. 38-49.

Karwatowska M., Tymiakin L. (red.), 2013, Humor w perspektywie kulturowo-językowej, Lublin.

Korpysz T., 2009, Emocje w języku - język w emocjach. Uwagi językoznawcy, w: Oblicza dojrzałości emocjonalnej dzieci i młodzieży, red. K. Franczak, M. Szpringer, Warszawa, s. 313-338.

Korpysz T., 2010, „Uśmiech” w pismach Cypriana Norwida, w: Człowiek. Słowo. Świat, red. J. Chojak, T. Korpysz, K. Waszakowa, Warszawa, s. 152-165.

Korpysz T., 2015, „Humor” w pismach Cypriana Norwida, w: W strone Norwida. Prace Warszawskiego Koła Norwidologicznego dedykowane Profesor Jadwidze Puzyninie, red. T. Korpysz, E.M. Rogowska, Warszawa, s. 89-103.

Krasowska A., 2013, Od „Zielonego Balonika” po „Potem”. Komizm słowny w kabarecie literackim, Warszawa. 
Kreja B., 1969, Stowotwórstwo rzeczowników ekspresywnych w języku polskim, Gdańsk.

Kwiatkowska A., Dżereń-Głowacka S. (red.), 2008-2009, Humor. Teorie - praktyka zastosowania, t. 1-2, Odcienie humoru, Piotrków Trybunalski.

Kwiatkowska A., Stanecka A. (red.), 2012, Humor. Teorie-praktyka-zastosowania, t. 3, Kody humoru, Piotrków Trybunalski.

Krzyżanowski J., 1984, Sztuka słowa. Rzecz o zjawiskach literackich, Warszawa.

Matusewicz C., 1976, Humor, dowcip, wychowanie, Warszawa.

Mazur J., Rumińska M. (red.), 2007, Humor i karnawalizacja we współczesnej komunikacji językowej, Lublin.

Mikołajczuk A., 2006, O wyrażaniu i komunikowaniu uczuć w języku polskim (na przykładzie radości), w: Wyrażanie emocji, red. K. Michalewski, Łódź, s. 84-93.

Mikołajczuk A., 2007, Uczucia „w rodzaju radości” $w$ świetle danych języka polskiego (radość, szczęście, zadowolenie, wesołość), w: Fenomen radości, red. A Grzegorczyk, J. Grad, P. Szkudlarek, Poznań, s. 65-73.

Mikołajczuk A., 2009, Obraz radości we współczesnej polszczyźnie, Warszawa.

Norwid C., 1971-1976, Pisma wszystkie, t. 1-11, wstęp i oprac. J.W. Gomulicki, Warszawa.

Nowakowska-Kempna I., 1986, Konstrukcje zdaniowe z leksykalnymi wykładnikami predykatów uczuć, Katowice.

Nowakowska-Kempna I., 1995, Konceptualizacja uczuć w języku polskim. Prolegomena, Warszawa.

Nowakowska-Kempna I., 2000, Konceptualizacja uczuć w języku polskim, t. 2, Data, Warszawa.

Pajdzińska A., 1990, Jak mówimy o uczuciach? Poprzez analizę frazeologizmów do językowego obrazu świata, w: Językowy obraz świata, red. J. Bartmiński, Lublin, s. 87-107.

Pałuszyńska E., 2002, Ekspresywne użycia nazw własnych $w$ nagłówkach, w: Tekst w mediach, red. K. Michalewski, Łódź, s. 309-313.

Passi I., 1980, Pochwała śmieszności, Warszawa.

Peisert M., 2006, Śmiech i uśmiech jako komunikaty paraleksykalne i kulturowe, w: Język a kultura, t. 18, Wielokulturowość w języku, red. A. Burzyńska-Kamieniecka, A. Dąbrowska, Wrocław, s. 233-240.

Puzynina J., 2000, Uczucia a postawy we współczesnym języku polskim, w: Język a kultura, t. 14, Uczucia w języku i tekście, red. I. Nowakowska-Kempna, A. Dąbrowska, J. Anusiewicz, Wrocław, s. 9-24.

Rybka M., Sławek J., 2004, O emocjonalności języka poezji księdza Jana Twardowskiego, w: Wokót językowej funkcji emocjonalnej. Fakty dawne $i$ współczesne, red. K. Wojtczuk, V. Machnicka, Siedlce, s. 196-206.

Siatkowska E., 1988, Pole semantyczne 'szczęścia'i pojęć pokrewnych w historii języka polskiego, „Prace Filologiczne” t. 34, s. 127-147.

Siatkowska E., 2013, „Humor” jako leksem wartościujący (aksjologiczny), w: Humor w perspektywie kulturowo-językowej, red. M. Karwatowska, L. Tymiakin, Lublin, s. 139-148. 
Skubalanka T., 1972, O ekspresywności języka, Lublin.

Smól J., 2006, O emocjach w gwarze uczniowskiej, w: Wyrażanie emocji, red. K. Michalewski, Łódź, s. 421-427.

Sobotka P., 2002, Negatywne uczucia w ,Vade-mecum” a Norwidowski horyzont aksjologiczny, w: Norwid a chrześcijaństwo, red. J. Fert, P. Chlebowski, Lublin, s. 421-448.

Sopolińska L., 2004, Operatory emotywno-oceniajace w języku mówionym, w: Funkcja emocjonalna jednostek językowych i tekstowych, red. K. Wojtczuk, A. Wierzbicka, Siedlce, s. 39-47.

Spagińska-Pruszak A., 2005, Język emocji. Studium leksykalno-semantyczne rzeczownika w języku polskim, rosyjskim i serbsko-chorwackim, Łask.

Sydiaczenko N., 2006, Konceptualizacja , szczęścia” $i$,,radości” widiolekcie poetyckim Czesława Miłosza, w: Wyrażanie emocji, red. K. Michalewski, Łódź, s. 551-560.

Szykulska K., 2003, Język emocji - foniczne środki ekspresji, „Poradnik Językowy” z. 5, s. 6-20.

Waszakowa K., 2008, „Uśmiech” jako stowo i gest mimiczny. Obraz uśmiechu we współczesnej polszczyźnie, w: Pojęcie - stowo - tekst, red. R. Grzegorczykowa, K. Waszakowa, Warszawa, s. 151-166.

Wieczorek K., 2000, Poczucie humoru a filozofia, w: Świat humoru, red. S. Gajda, D. Brzozowska, Opole, s. 13-25.

Wierzbicka A., 1971, Kocha, lubi, szanuje. Medytacje semantyczne, Warszawa.

Wierzbicka A., 1999a, Emocje. Język i ,skrypty kulturowe”, w: eadem, Język - umyst - kultura. Wybór prac, red. J. Bartmiński, Lublin, s. 163-189.

Wierzbicka A., 1999b, Mówienie o emocjach. Semantyka, kultura i poznanie, w: eadem, Język - umyst - kultura. Wybór prac, red. J. Bartmiński, Lublin, s. 138-162.

Wojtczuk K., 2004, Wykrzykniki polskie jako jednostki składni emocjonalnej. Próba opisu wybranych tendencji funkcjonalnych, w: Funkcja emocjonalna jednostek językowych i tekstowych, red. K. Wojtczuk, A. Wierzbicka, Siedlce, s. 291-301.

Wojtczuk K. 2006, Śmiech i płacz w języku i kulturze. Zarys problematyki, w: Wyrażanie emocji, red. K. Michalewski, Łódź, s. 102-110.

Wojtczuk K., 2009, O emocjach bez emocji, czyli o polskich badaniach lingwistycznych nad emocjami w dziesięcioleciu 1997-2007. Stan, tendencje, perspektywy, w: Rejestr emocjonalny języka, red. K. Wojtczuk, V. Machnicka, Siedlce, s. 263-278.

Zawilska D., 2004, O stylistyczno-emocjonalnej funkcji pisowni $i$ interpunkcji, w: Funkcja emocjonalna jednostek językowych i tekstowych, red. K. Wojtczuk, A. Wierzbicka, Siedlce, s. 305-314.

Zimny R., 2004, Skladnik emotywny w reklamach samochodów, w: Funkcja emocjonalna jednostek językowych i tekstowych, red. K. Wojtczuk, A. Wierzbicka, Siedlce, s. 315-326.

\section{Słowniki}

Doroszewski W. (red.), 1958, Stownik języka polskiego, t. 2, D-G, Warszawa.

Dubisz S. (red.), 2003, Uniwersalny stownik języka polskiego, t. 1, A-J, Warszawa. 
Głowiński M., Kostkiewiczowa T., Okopień-Sławińska A., Sławiński J. (red.), 1988, Stownik terminów literackich, Wrocław-Warszawa-Kraków-Gdańsk-Łódź.

Górski K., Hrabec S., 1962, Słownik języka Adama Mickiewicza, t. 3, H-K, Wrocław.

Gruszczyński W. (red.), Elektroniczny stownik języka polskiego XVII i XVIII wieku, $<$ http://www.sxvii.pl>, 15.09.2014.

Karłowicz J., Kryński A., Niedźwiedzki W. (red.), 1900, Stownik języka polskiego, t. 2, $H-M$, Warszawa.

Koneczna H., Doroszewski W. (red.), 1965, Stownik języka Jana Chryzostoma Paska, t. $1, A-N$, Wrocław.

Kucała M. (red.), 1994, Stownik polszczyzny Jana Kochanowskiego, t. 1, A-H, Kraków.

Linde M.S.B., 1859, Stownik języka polskiego, t. 2, G-L, Lwów.

Mayenowa M.R. (red.), 1974, Stownik polszczyzny XVI wieku, t. 8, Gora-irzyk, Wrocław-Warszawa-Kraków-Gdańsk.

Puzynina J., Korpysz T., 2009, Internetowy stownik języka Cypriana Norwida, <http:// www.slownikjezykanorwida.uw.edu.pl>, 15.09.2014.

Sławski F., 1952-1956, Słownik etymologiczny języka polskiego, Kraków.

Urbańczyk S. (red.), 1956-1959, Stownik staropolski, t. 2, D-H, Wrocław-Kraków-Warszawa.

Zdanowicz A. (red.), 1861, Stownik języka polskiego, t. 1, A-O, Wilno.

Żmigrodzki P. (red.), 2007, Wielki słownik języka polskiego, <http://www.wsjp.pl>, 15.09.2014. 